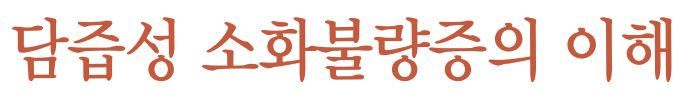

대구파티마병원 소화기내과

김현수

\title{
Understanding the Biliary Dyspepsia
}

\author{
Hyunsoo Kim \\ Division of Gastroenterology and Hepatology, Department of Internal Medicine, Daegu Fatima Hospital, Daegu, Korea
}

Functional dyspepsia is a very common disease and there are two types of dyspepsia. One is functional dyspepsia in the gastrointestinal tract and the other is pancreatobiliary dyspepsia. Biliary dyspepsia is caused by biliary tract disease and can even cause biliary pain. Acalculous biliary pain (ABP) is biliary colic without gallstones, it is caused by functional biliary disorder or structural disorders such as microlithiasis, sludges or parasitic infestation like Clonorchiasis. The endoscopic ultrasonography is helpful tool for differential diagnosis of ABP. Although sphincter of Oddi manometry (SOM) is performed for the confirmative diagnosis of sphincter of Oddi dysfunction (SOD), several non-invasive tests have been studied because of some practical limitations and invasiveness of SOM itself. In fact, the most clinically used easy test to diagnose functional biliary disorder is quantitative hepatobiliary scintigraphy and it can distinguish gallbladder dyskinesia, SOD, or combined type. Initial treatment of functional biliary disorder is adequate dietary control and medication, but if the symptoms worsened or recurred frequently, laparoscopic cholecystectomy could be performed with gallbladder dyskinesia. If SOD is suspected, additional SOM should be considered and endoscopic sphincterotomy (EST) can be done according to the outcome. If the SOM is not available, the patient could be diagnosed by stimulated ultrasound.

Korean J Pancreas Biliary Tract 2018;23(4):150-158

Keywords: Biliary dyspepsia, Gallbladder dyskinesia, Sphincter of Oddi dysfunction, Hepatobiliary scintigraphy

\begin{abstract}
Received Jul. 29, 2018
Revised Sep. 5,2018

Accepted Sep. 10, 2018
\end{abstract}

Corresponding author: Hyunsoo Kim Division of Gastroenterology and Hepatology, Department of Internal Medicine, Daegu Fatima Hospital, 99 Ayang-ro, Dong-gu, Daegu 41199, Korea Tel. +82-53-940-7222 Fax. +82-53-940-7458 E-mail; khsmhj@gmail.com

ORCID: https://orcid.org/0000-0001-5572-5453

This is an Open Access article distributed under the terms of the Creative Commons Attribution Non-Commercial License (http:// creativecommons.org/licenses/by-nc/3.0/) which permits unrestricted non-commercial use, distribution, and reproduction in any medium, provided the original work is properly cited.

Copyright $\odot 2018$ by The Korean Journal of Pancreas and Biliary Tract

\section{서 론}

소화불량증(dyspepsia)은 아주 흔히 외래에서 접할 수 있는 증상 중의 하나로 발생 위치에 따라 식도, 위, 십이지장 등의 상부위장관에 의한 소화불량증과 췌담관 질환에 의한 소화불량증이 있다. 한편 췌담관성 소화불량증은 담즙성 소화불량증(biliary dyspepsia)과 췌장성 소화불량증(pancreatic dyspepsia)으로 나눌 수 있으며, 주요 원인으로는
기질적인 췌담관 질환(예, 담석증, 종양, 만성 췌장염 등)과 기능성 췌담관 질환이 있다. ${ }^{1}$

기능성 위장관 질환(functional gastrointestinal disorder)이란 증상을 설명할 만한 구조적, 전신적 또는 대사성 질환 없이 소화관 증상이 발생하는 경우를 말하는데, 2016년 로마진단 기준 IV (Rome IV)에 의하면 위장관에 기인한 소화불량증을 '기능성 소화불량증(functional dyspepsia)'이라 하고, 췌담관에 기인한 소화불량증에는 '기능성 담낭 질환' 및 '오디괄약근 
기능이상증(담도, 췌장)' 등이 있다. ${ }^{2}$ 본 고찰에서는 상기 여러 원인의 소화불량증 중 담즙성 소화불량증에 대하여 알아보 고자 하며, 특히 기존에 잘 알려진 담석 또는 종양 질환을 제 외한 기능성 질환을 중심으로 문헌고찰과 함께 기술하고자 한다.

\section{본 론}

\section{1. 유병률}

소화불량증은 가장 흔한 기능성 소화기 질환 중 하나로, 유 병률은 전체 미국 인구의 약 $10-45 \%$ 정도로 다양하게 보고되고 있다. ${ }^{3}$ 담즙성 소화불량증의 유병률은 현재까지 소수의 연구 만이 시행되어 정확하게 알려져 있지 않으며, 이전의 한 연구에서는 전체 소화불량증 환자의 약 $5 \%$ 정도에서 담즙성 소화불량증이 관찰되었다고 보고한 바 있다. ${ }^{4}$ 이탈리아에서 시행된 연구에서는 남자 $7.6 \%$ 와 여자 $20.7 \%$ 에서 무결석 담관통이 관찰되었다고 보고하기도 하였다. ${ }^{5,6}$ 최근 20 년간 담즙성 소화불량증은 새로운 담낭절제술의 적응증이 되었으며 담낭절제술을 시행받은 성인의 약 $10-20 \%$ 에서 수술의 적응 증으로 조사되었다. ${ }^{7}$ 한편 담낭절제술 후 다시 소화불량증이 발생할 수 있는데 미국 조사에 의하면 약 $1.5 \%$ 에서 수술 후 증상의 재발을 보였으며 남자 $0.6 \%$, 여자 $2.3 \%$ 의 유병률을 보였다. ${ }^{8}$ 한편 국내 전체 소화불량증 유병률은 $8.1-46.0 \%$ 며 ${ }^{9}$ 담즙성 소화불량증의 유병률에 대한 대규모 연구는 아직 없는 상태이다.

\section{2. 정의 및 특징}

영상 검사 담석이나 종양 등의 특별한 이상 소견이 없고 간기능 검사 수치가 정상이면서 지속적 담즙성 소화불량 또는 통증을 나타내는 경우를 기능성 담관통(functional biliary pain)이라 정의하며, 비결석성 담관통(acalculous biliary pain, $\mathrm{ABP}$ ) 또는 담낭 운동이상증(gallbladder dyskinesia), 만성 비결석성 담낭기능부전(chronic acalculous gallbladder dysfunction), 비결석성 담관 질환(acalculous biliary disease) 그리고 만성 비결석성 담낭염(chronic acalculous cholecystitis) 으로 혼용되고 있다. ${ }^{10}$

기능성 담관계 질환(functional biliary disease)은 기능성 담낭 질환 및 오디괄약근 기능이상증으로 나눌 수 있으며, 로마진단기준 IV에 의한 진단기준으로는 ${ }^{11}$ 기질적 질환이 없이 발생되는 명치 및/또는 우상복부 통증으로 1) 30 분 이상의
지속적 통증, 2) 매일 발생하지 않는 불규칙한 재발 간격, 3) 일상생활의 장애 또는 응급실을 방문할 정도의 심한 통증, 4) 배변과 관련이 없으며( $20 \%$ 미만), 5$)$ 체위변화 또는 위산 억제와 관련이 없는 경우( $20 \%$ 미만)로 정의하였다. 그리고 추가적인 항목으로는 1) 오심 및 구토, 2) 등 또는 우견갑골 하방으로의 방사통, 3 ) 잠에서 깨어날 정도의 통증 등이 있다 (Table 1). 통증 지속시간은 보통 30분 이상 지속하나 6시간을 넘기지는 않는 경우가 많으며 만약 통증이 6시간 이상 계속 지속이 되면 담석 등의 기질적 원인을 먼저 생각해 보아야 한다. ${ }^{12}$ 기능성 담낭 질환(functional gallbladder disorder)은 1) 상기 기술된 담관통, 2) 담석이나 다른 기질적인 질환이 없을 때로 정의하며, 추가적인 항목으로 1) 담낭스캔상 담낭배출능 감소, 2) 정상 간기능 수치 및 정상 아밀라제/리파제 수치 등 이다. 담도 오디괄약근 기능이상증(functional biliary sphincter disorder)은 1) 상기 담관통, 2) 간기능 이상 또는 확장된 담관, 3) 담석이나 다른 기질적 질환이 없을 때로 정의하며, 추가적인 항목으로는 1) 정상 아밀라제/리파제 수치,

Table 1. Rome IV, gallbladder and sphincter of Oddi disorders (modified from Cotton et al. ${ }^{11}$ )

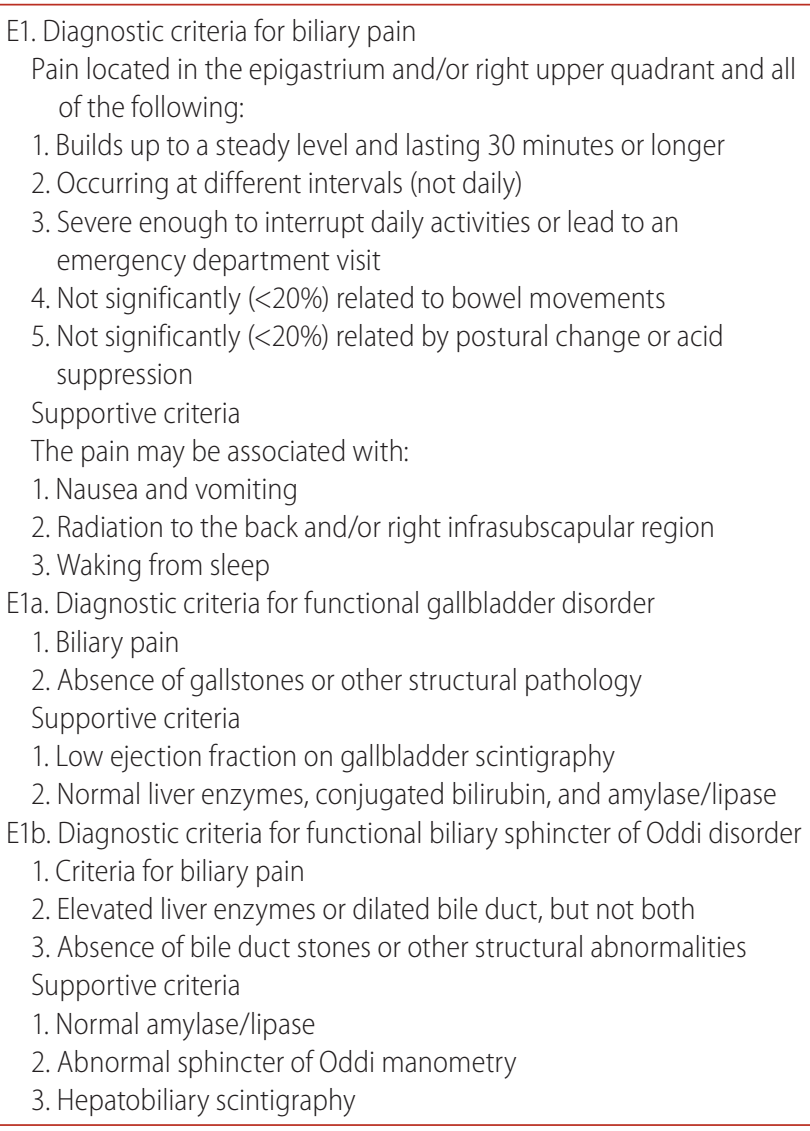


2) 오디괄약근 내압 검사 이상, 3) 간담도 스캔상 이상 소견 등이다. 췌관 오디괄약근 기능이상증(functional pancreatic sphincter disorder)은 1) 재발성 췌장염, 2) 다른 췌장염 원인 배제, 3) 내시경 초음파상 정상, 4) 오디괄약근 내압 검사 이상 소견이 관찰될 때 진단될 수 있다.

\section{3. 발생기전}

정상적으로 담즙(bile)은 대부분인 수분을 제외한 성분 중 67\%의 담즙산(bile acid)과 인지질(phospholipid), 콜레스테롤, 빌리루빈, 단백질, 전해질 등으로 구성된다. 일반적으로 공복 시에는 대부분의 담즙이 담낭에 저장되어 있으며 약 $25 \%$ 정도 만이 십이지장으로 배출된다. 하지만 식사 후에는 secretin의 영향으로 담즙내 수분 및 전해질 분비가 증가하여 담즙 양이 증가되고 cholecystokinin (CCK)의 작용으로 인한 담낭 수축과 오디괄약근 이완으로 담즙이 십이지장으로 다량 배출된다. 이러한 담즙 배출 장애가 발생될 때 소화불량 증세, 심지어 통증까지 발생할 수 있는데 이러한 것을 담즙성 소화 불량증(biliary dyspepsia) 또는 담관통(biliary pain)이라 한다. 담관통 유발 병리기전은 급성기에서 담관내 압력 증가 및 염증 반응에 의한 것이 주이며, 만성적인 경우에는 담관의 내장 과민성(visceral hypersensitivity or hyperalgesia)과 심리적인 영향도 같이 작용한다. ${ }^{13}$

\section{4. 진단 및 감별진단}

담즙성 소화불량증은 병력 청취 그리고 이학적 소견과 더불어 여러 가지 영상학적인 검사, 그리고 담관계 기능 검사로 진단될 수 있다. 증상은 상기 기술된 로마진단기준 IV에 의한 담관통 증상을 나타내며, 식사 특히 과식과 지방식이로 증상 악화 소견을 보인다. 주로 젊거나 중년 여성에서 많으며 비만 또는 다산과 같은 담석증의 위험인자를 공유한다. 주요 이학적 소견으로 우상복부 타진성 압통(percussion tenderness) 또는 명치 압통이 있다. 우상복부 타진성 압통을 나타낼 수 있는 질환으로는 ${ }^{14}$ 담관계 질환(담석증, 담도 협착, 담도 종양, 담도염, 급성 또는 만성 담낭염, 기생충 질환, 혈담즙증, 유두괄약근 기능이상증 등), 간 또는 간 주변 질환(바이러스성 또는 독성 간염, Fitz-Hugh-Curtis 증후군, 지방간, 심장 질환 이나 빈혈 등에 의한 간 울혈 상태 등) 등이 있고, 그 외 우측 하늑골 근처의 근골격계 질환(늑골 손상 또는 골절, Tietze 증후군, 근육통) 등이 있으며 전부 우상복부 타진성 압통을 나타낼 수 있어 감별에 주의해야 한다.
영상학적인 진단으로는 담석증이나 담도 종양을 배제하기 위하여 복부 초음파 검사 또는 복부 전산화단층촬영 (computed tomography, CT) 검사가 필요하며, 필요시 $\mathrm{ERCP}$ 또는 $\mathrm{MRCP}$ 를 시행할 수 있고 때로는 EUS도 시행할 수 있다. 담도 기능 검사로는 제일 확진적인 것은 ERCP하 오디괄약근 내압 검사이며 최근에는 비침습적인 여러 검사에 대한 연구가 진행되고 있다.

담즙성 소화불량증의 원인으로는 기질적인 원인과 기능성 원인이 있는데, 기질적인 원인 중 가장 많은 것이 담석증이며 그 외 종양, 협착 등과 감별해야 하며 혈액 생화학 검사 및 복부 초음파 또는 CT 촬영으로 비교적 쉽게 감별이 가능하다. 하지만 일반적인 영상 검사상 담석이나 종양이 없는 경우, 기능성 원인과 감별을 해야 하는 질환으로는 담즙 슬러지 (sludge) 또는 미세담석증(microlithiasis), 담석의 자연 배출 후 상태, 주변 십이지장 과민성(hypersensitivity of the adjacent duodenum), 그리고 과민성 장증후군 등이 있으며 국내 등 일부 국가에서는 간흡충(Clonorchis sinensis) 등의 기생충도 한 원인이 된다(Table 2).

1) 오디괄약근 기능이상증(sphincter of Oddi dysfunction, SOD)

SOD는 1887년 Ruggero Oddi에 의하여 처음 기술되었는데 오디괄약근 수축 이상으로 인한 질환을 말한다. SOD는 발생 기전에는 크게 두 가지가 있으며 하나는 해부학적인 변화인 오디괄약근 협착(SO stenosis)과 운동질환인 오디괄약근 운동장애(SO dyskinesia)가 있으며 일반적으로 SOD로 혼합 하여 사용되고 있다. ${ }^{15} \mathrm{SO}$ stenosis는 췌장염, 담석이나 슬러 지의 자연 배출 후, 수술 중 손상, 감염(Strongyloides, Cytomegalovirus 또는 Cryptosporidium 등) 그리고 선근종(adenomyomatosis) 등으로 인하여 $\mathrm{SO}$ 의 염증이나 섬유화가 발생 되어 발병한다. 한편 SO dyskinesia는 호르몬이나 신경 전달 의 이상으로 인한 motor 기능 이상으로 인하여 발생될 수 있

Table 2. Causes of acalculous biliary pain

Abnormal gallbladder emptying (gallbladder dyskinesia) Sphincter of Oddi dysfunction An overly sensitive biliary tract Microscopic stones or sludges Spontaneously passed gallstones Hypersensitive duodenum Functional gastrointestinal disorders, e.g., irritable bowel syndrome Parasitic infestation, e.g., Clonorchis sinensis 
으며 약물로도 발생이 가능하다. ${ }^{15}$

$\mathrm{SOD}$ 는 modified Milwaukee 분류에 의하여 3 가지 형으로 나눌 수 있는데 과거 전통적인 Milwaukee 분류보다 좀 더 완화 되었다(Table 3). ${ }^{16}$ 진단기준은 담관통이 있으며 1) 2회 이상의 혈액 검사 이상(aminotransferases, bilirubin 또는 alkaline phosphatase가 정상의 두 배 초과), 2) CBD 직경이 초음파 상 $8 \mathrm{~mm}$ 초과로 단순화되었으며(ERCP 소견은 삭제됨), 1형은 2 개 다 만족, 2 형은 1 개 만족, 1 형은 전부 정상일 때로 정의 되었다. 이 분류법은 오디괄약근 내압 검사(SO manometry, $\mathrm{SOM})$ 의 검사 필요성과 치료로 내시경적 유두괄약근 절개술 (endoscopic sphincterotomy, EST)의 효과 및 타당성의 근거가 된다. 즉 제 1 형에서는 임상 양상 만으로 진단이 가능하며 $\mathrm{SOM}$ 이 필요 없이 바로 $\mathrm{EST}$ 를 시행할 수 있다. 하지만 제2형, 제3형은 SOM이 필요하고 SOM에 이상이 있는 경우에 EST를 시행할 수 있다.

$\mathrm{SOD}$ 는 주로 젊은 중년의 여성에서 많이 발생하며 소아 에서도 발생될 수 있다. 담낭을 수술한 후 더 많이 발생되나 수술 전에도 발견될 수 있으며 아직 정확한 유병률에 대한 통계는 없다. 수술을 시행한 담석 환자에서 수술 전 시행한 $\mathrm{SOM}$ 상 $11.6 \%$ 에서 SOD가 동반되었고 다른 한 보고에서는 담관통을 가지고 검사상 담석이 없는 환자의 약 $53 \%$ 에서 $\mathrm{SOD}$ 소견을, $49 \%$ 에서 담낭 운동장애 소견이 관찰되었으며 $\mathrm{SOD}$ 환자에서 담낭 운동장애는 절반 정도 동반되었다. ${ }^{17}$ Sherman 등 $^{18}$ 은 115 명의 $\mathrm{ABP}$ 환자에서 $\mathrm{SOM}$ 을 시행한 결과 약 $51 \%$ 에서 SOD 소견을 관찰하였으며 제 1 형에서는 $86 \%$, 제 2 형에서는 $55 \%$ 그리고 제 3 형에서는 $28 \%$ 에서 $\mathrm{SOM}$ 에 이상
소견이 관찰되었다.

$\mathrm{SOD}$ 는 담관 및 췌관에 다 발생할 수 있는 질환으로 주요 임상 양상은 담관 괄약근(sphincter choledochus)에 이상이 있으면 $\mathrm{ABP}$ 로, 췌관 괄약근(sphincter pancreaticus)에 이상이 있으면 특발성 급성 재발성 췌장염(idiopathic acute recurrent pancreatitis, IARP)의 형태로 나타나며 양 쪽 다 같이 나타 나는 경우도 있다. 한 연구에서 원인 미상의 췌담관 통증 환자 중 $19 \%$ 에서 췌관 괄약근 이상, $11 \%$ 에서 담관 괄약근 이상, $31 \%$ 에서 양쪽 다 이상 소견을 보여 전체의 $61 \%$ 에서 $\mathrm{SOD}$ 로 진단되었다. ${ }^{19}$

$\mathrm{SOD}$ 의 증상은 담낭 운동장애와 증상이 거의 비슷하기 때문에 임상적인 구별이 어려우며 담낭이 있는 경우에도 발생될 수 있으나 사전에 진단하기 힘들기 때문에 수술 전 담낭 및 SO에 대한 기능평가가 중요하다. SOD는 주로 담낭절제술을 받은 후 통증이 재발되어 진단이 되는데, 수술 후 약 $10-20 \%$ 에서 수술 전과 유사한 담관통 재발을 호소하였다. 담낭절제술 후 증후군(post-cholecystectomy syndrome)은 담낭절제술 후 다시 담관통이 재발되는 상태를 말하며 그 원인으로는 수술 전 간과된 총담관 결석, 슬러지, 협착, 종양 또는 $\mathrm{SOD}$ 등이 있다. 하지만 실제로 전체 담낭절제술을 받은 환자의 약 $1 \%$ 만이 $\mathrm{SOM}$ 상 $\mathrm{SOD}$ 로 인한 담낭절제술 후 증후군으로 진단되었다. ${ }^{20}$ $\mathrm{SOD}$ 에 의한 담낭절제술 후 증후군의 발생 기전은 정확히 밝혀져 있지 않으나 수술 전 진단이 안 된 SOD 환자가 수술 후 담낭의 저장 기능 상실로 인한 담도압의 갑작스러운 상승 으로 통증이 발생될 수 있으며, 또 수술시 담낭으로부터 $\mathrm{SO}$ 로 지나가는 신경이 담낭관을 절제할 때 같이 손상을 받아 발생

Table 3. Modified Milwaukee classification of SOD (modified from Behar et al. ${ }^{16}$ )

\begin{tabular}{ll}
\hline SOD type & \multicolumn{1}{c}{ Definition } \\
\hline Biliary type I & $\begin{array}{l}\text { Typical biliary type pain } \\
\text { Liver enzymes (AST, ALT or ALP) }>2 \text { times normal limit documented on at least 2 occasions during episodes of pain } \\
\text { Dilated CBD }>8 \text { mm in diameter on USG } \\
\text { Positive manometry for biliary SOD (seen in 65-95\% of patients) }\end{array}$ \\
\hline Biliary type II & Biliary type pain and one of the above criteria (laboratory or imaging) \\
Biliary type III & Biliary type pain only \\
Pancreatic type I & $\begin{array}{l}\text { Pancreatic type pain } \\
\text { Amylase and/or lipase }>2 \text { times upper normal limit on at least 2 occasions during episodes of pain }\end{array}$ \\
\hline Pancreatic type II & Dilated pancreatic duct (head $>6 \mathrm{~mm}$, body $>5$ mm) \\
Pancreatic type III & Pancreatic type pain, and one of the above criteria (laboratory or imaging) \\
\hline
\end{tabular}

SOD, sphincter of Oddi dysfunction; AST, aspartate aminotransferase; ALT, alanine aminotransferase; ALP, alkaline phosphatase; CBD, common bile duct; USG, ultrasonography. 
하는 것으로 추정되고 있다.

$\mathrm{SOD}$ 의 진단에는 침습성 진단법과 비침습성 진단법이 있다(Table 4). SOM은 ERCP를 통한 침습성 진단법으로 $\mathrm{SOD}$ 를 진단할 수 있는 가장 대표적인 gold standard 검사법 이다. SOM의 적응증으로는 원인 미상의 담도 또는 췌장 통증, 특발성 재발성 췌장염, 담낭절제술 후 증후군, 임상적으로 $\mathrm{SOD}$ 가 의심될 때, 간기능수치 이상을 동반한 복통, EST 전후 비교를 위하여 원인 미상의 확장된 담관 또는 췌관이 있는 경우 등이다. ${ }^{21} \mathrm{SOM}$ 의 진단기준에 대해서는 아직까지도 논란이 많으나 현재 사용되고 있는 기준으로는(Table 5) 1) $\mathrm{SO}$ 기저압 증가 $(\geq 40 \mathrm{mmHg}), 2)$ 위상파의 최고압 증가 ( $\geq 240 \mathrm{mmHg}), 3)$ 수축빈도 증가( $\geq 8 /$ 분), 4) 역방향 전파 (retrograde propagation) 증가 $(\geq 50 \%), 5)$ CCK에 대한 반응 이상(역설적 수축) 등이며 이 중 SO 기저압 증가가 EST 후 효과를 예측하는데 가장 좋은 지표라고 입증이 되어 있다. ${ }^{22}$ SO stenosis와 dyskinesia의 감별을 위해서는 평활근 이완제인 amyl nitrite 또는 glucagon 주입 후 SO 이완 유무, 즉 stenosis는 이완이 안되는 점으로 감별을 할 수 있다. $\mathrm{SOM}$ 의 문제점은 1) 검사의 위음성이 많고(민감도 SOD 1형: 65-95\%, 2형: 50-63\%, 3형: 12-59\%), 2) 장비 및 술기에 따른 영향을 많이 받으며, 3) 전처치 약물에 영향을 받는데, 사용 가능 약물은 propofol, midazolam, 또는 diazepam 등이다, 4) 검사 자체가 침습적이며 비교적 합병증이 많은데, $4-30 \%$ 의 유병률 및 $0.4 \%$ 의 사망률을 보고하였으며 특히 합병증 중 췌장염 발생이 $10-15 \%$ 로 증가 되었다. 5) 재현성이 불균일하며, 6) 시술자에 따라 성공률의 차이(54-87\%) 및 결과의 차이가 있고, 7) SOM 이상 소견과 환자 증상 간의 일치성에 문제가 있다는 점 등이다. 이러한

\section{Table 4. Diagnosis of SOD}

\begin{tabular}{l}
\hline Invasive methods \\
1. ERCP \\
2. Endoscopic sphincter of Oddi manometry (SOM) \\
Non-invasive methods \\
1. Provocation test \\
- Nardi test (morphine-prostigmin provocation test) \\
2. Stimulation test \\
- Stimulated transabdominal US (s-US) \\
- Endoscopic ultrasonography-secretin test (EUS-s) \\
- Secretin stimulated MRCP (sS-MRCP) \\
3. Quantitative hepatobiliary scan
\end{tabular}

SOD, sphincter of Oddi dysfunction; ERCP, endoscopic retrograde cholangiopancreatography; US, ultrasonography; MRCP, magnetic resonance cholangiopancreatography.
$\mathrm{SOM}$ 의 단점을 극복하기 위하여 구미에서는 여러 가지 비침습적인 기능 검사에 대하여 연구 보고하고 있다.

$\mathrm{SOD}$ 진단에 대한 비침습적 검사로는 morphine-prostigmin 유발 검사(Nardi 검사), 자극 복부초음파 검사(stimulated US, s-US), secretin 자극 내시경초음파 검사(EUS-s), secretin 자극 MRCP 검사(ss-MRCP), 정량적 간담도 신티그라피 (quantitative hepatobiliary scintigraphy) 등이 있다. ${ }^{23} \mathrm{Nardi}$ 검사는 morphine $10 \mathrm{mg}$ 및 neostigmine $1 \mathrm{mg}$ 근육 또는 피하 주사를 하여 통증을 유발시키는데, 주사 후 전형적인 통증 및/또는 췌장 또는 간기능 수치 4 배 이상 상승시 양성으로 판정한다. 제한점으로는 정상인의 약 $60 \%$ 에서도 아밀라제/ 리파제 상승을 일으킬 수 있고, 과민성 장증후군 환자의 약 $40 \%$ 에서도 통증이 유발될 수 있다. ${ }^{24}$ 담즙 또는 췌액 분비에 대한 자극 방법으로는 주로 지방식이(예, 계란 2개) 또는 secretin 주사로 시행한다. 자극 초음파 검사는 자극 전 및 45 분 후를 비교하는데 전형적인 통증 및/또는 자극 전보다 상부 총담관(proximal CBD)이 $2 \mathrm{~mm}$ 이상 확장 또는 췌관이 $1 \mathrm{~mm}$ 이상 확장시 양성으로 판정한다. 이 검사법은 비교적 저렴하며 믿을 만하고 재현성이 좋다. 하지만 시간이 많이 걸리고 췌관을 55-90\%에서만 관찰할 수 있어 제한점이 있다. 자극 내시경초음파 검사는 이러한 췌관 관찰의 제한점을 보완하기 위하여 시행되며 내시경을 해야 되기 때문에 자극은 secretin 주사로만 시행한다. EUS 관찰 하에서 secretin $1 \mathrm{IU} / \mathrm{kg}$ 주입 후 투입 전 및 투입 후 15 분 동안 매분마다 췌관의 지름 측정하여 투입 전보다 $1 \mathrm{~mm}$ 이상 확장시 양성으로 판정한다. 단점은 침습적이고 고비용이며 시술자에 의한 의존도가 높다. Secretin 자극 MRI 검사 역시 자극 후 췌관을 측정하는 검사로 secretin 투입 전 및 투입 후 15 분까지 매분마다 검사를 시행 하여 췌관의 직경이 투입 전보다 $1 \mathrm{~mm}$ 이상 지속된 증가가 있으면 양성으로 판정하였다. 한 연구에서 SOM과의 일치율이 $86.7 \%$ 로 높았으나 ${ }^{25}$ 대규모의 연구가 없으며 국내에서는 비용

Table 5. Normal and abnormal values of SOM (modified from Lee ${ }^{22}$ )

\begin{tabular}{lcc}
\hline Parameter & Normal & Abnormal \\
\hline Basal pressure $(\mathrm{mmHg})$ & $3-35$ & $\geq 40$ \\
Amplitude $(\mathrm{mmHg})$ & $95-195$ & $\geq 240$ \\
Frequency $(\mathrm{n} / \mathrm{min})$ & $2-6$ & $\geq 8$ \\
Retrograde propagation (\%) & $<50$ & $\geq 50$ \\
Response to CCK & Inhibit & Contract \\
\hline
\end{tabular}

SOM, sphincter of Oddi manometry; CCK, cholecystokinin. 
문제가 발생할 수 있다. 정량적 간담도 신티그라피는 간담도 질환에 대한 기능 검사로 가장 잘 알려져 왔으며 주로 $\mathrm{SO}$ 에 대한 기능과 담낭에 대한 기능을 평가하는데 유용하다. 담낭 절제술 후 SOD 진단에 대하여 Sostre 등 ${ }^{26}$ 은 6 개의 기준을 가지고 점수화하였으며 총 12점 중 6점 이상시 양성으로 진단하였다(Table 6). 그 외 십이지장 도달시간(duodenal arrival or appearance time, DAT)이 20분 이상 연장되거나 간문부 십이지장 통과시간(hilum to duodenum transit time, HDTT)이 10 분 이상 연장된 소견이 담낭절제술 후 SOD 진단에 중요한 소견이라 하겠다. ${ }^{15,27}$ 이러한 신티그라피 검사는 민감도가 낮고 재현성이 떨어지며 SOM과의 일치도에도 논란이 있다는 제한점이 있었으나 치료로 EST 시행 후 그 효과를 미리 예측하는데 비교적 유용하였으며 ${ }^{28}$ 특히 SOD 제2형 또는 3형에서는 morphine을 사용하여 자극을 한 후 검사를 시행하면 그 성적이 더 개선되었으며 ${ }^{29}$ 자극 초음파와 신티그라피를 혼합하여 같이 시행한 경우에 낮은 민감도를 개선할 수 있었고 EST 후의 치료 효과를 예측하는데 역시 유용하였다. ${ }^{30}$

Table 6. Criteria for scoring scintigrams (modified from Sostre et al. ${ }^{26}$ )

\begin{tabular}{ll}
\hline Criteria & Score \\
\hline 1. Peak time & \\
a. Less than 10 minutes & 0 \\
b. 10 or more minutes & 1 \\
2. Time of biliary visualization & \\
a. Less than 15 minutes & 0 \\
b. 15 or more minutes & 1 \\
3. Prominence of biliary tree & \\
a. Not prominent & 0 \\
b. Prominent major intrahepatic ducts & 1 \\
c. Prominent small intrahepatic ducts & 2 \\
4. Bowel visualization & \\
a. Less than 15 minutes & 0 \\
b. $15-30$ minutes & 1 \\
c. More than 30 minutes & 2 \\
5. CBD emptying & \\
a. By more than $50 \%$ & 0 \\
b. Less than $50 \%$ & 1 \\
c. No change & 2 \\
d. Shows increasing activity & 3 \\
6. CBD-to-liver ratio & \\
a. CBD60 liver60 & \\
b. CBD60 higher than liver60 but lower than liver15 & 1 \\
c. CBD60 higher than liver60 and equal to liver15 & 2 \\
d. CBD60 higher than both liver60 and liver15 & 3 \\
\hline
\end{tabular}

CBD, common bile duct.
한편 담낭절제술을 받지 않은 정상적인 담낭 환자에서의 $\mathrm{SOD}$ 진단은 좀 더 복잡한데 이는 담즙 배출이 담낭의 영향을 많이 받기 때문이다. 일반적으로 60 분 내에 소장이 조영되지 않으면 $\mathrm{SO}$ 의 압력이 올라간 것으로 정의하였으나 ${ }^{31}$ 아직 연구가 더 필요하다.

\section{2) 담낭 운동장애(gallbladder dyskinesia)}

담낭 운동장애는 담석과 같은 기질적인 병변 없이 담낭자체의 운동기능이상으로 담도성 증상을 나타내는 상태로 주로 담낭 배출장애에 의한다. 증상은 전형적인 담관통 또는 담즙성 소화불량증을 나타내며, 담낭이 심하게 팽창이 되어 있는 경우에는 Murphy's sign을 관찰할 수 있다. 빌리루빈을 포함한 간기능 검사가 정상으로 $\mathrm{SOD}$ 제3형과 감별이 필요하며 복부 초음파 또는 CT 등으로 미세담석, 슬러지를 배제해야 한다. 진단은 영상 검사상 담석 등이 배제된 상태에서 간담도 신티 그라피상 담낭 박출계수(gallbladder ejection fraction, GBEF)가 $40 \%$ 미만일 때 할 수 있다.

\section{5. 치료}

$\mathrm{SOD}$ 의 치료는 내과적 약물 치료, 내시경적 치료 그리고 수술적인 치료가 있다. 내과적 치료로는 저지방 식이와 과식을 피하는 것이 좋다. 투약으로는 nifedipine과 같은 칼슘통로 차단제 또는 nitrate 등과 같은 평활근육이완제의 효과가 보고되어 있다. 하지만 장기간 사용에 대한 자료가 부족하고 약 $1 / 3$ 에서 어지러움, 기립성 저혈압, 두통 등의 부작용이 보고되고 있다. ${ }^{22}$ 그 외 여러 종류의 위장관 운동촉진제나 UDCA, 신경안정제, octreotide 주사, prostaglandin E1 유사체인 alprostadil alfadex 그리고 단백질 차단제인 gabexate mesilate 등에 대한 연구가 있다. ${ }^{16,32}$ 한편 GB34 포인트에 대한 전 기침(electroacupuncture)의 효과에 대한 국내 보고도 있다. ${ }^{33}$

내시경적 유두괄약근 절개술(endoscopic sphincterotomy, $\mathrm{EST}$ )은 현재 SOD 치료의 표준이다. Geenen 등의 연구에 의하면 SO 기저압이 상승한 경우 시술 후 $90 \%$ 이상에서 호전을 보고하였고 다른 보고에서도 대체적으로 60-70\% 정도로 효과가 보고되었다. ${ }^{22}$ 제일 문제가 되는 합병증은 췌장염으로 일반적인 ERCP 후 췌장염 발생률 3-5\%에 비하여 $12.5-27 \%$ 로 높다. 그러므로 SOD 제 2,3 형, 특히 제 3 형에서는 $\mathrm{SOM}$ 에 이상이 있고 생활에 지장을 줄 정도로 이상이 있을 때만 시술을 고려해야 하겠다. ${ }^{22}$ 일부 센터에서는 제 2 형에서 $\mathrm{SOM}$ 검사 없이 경험적 $\mathrm{EST}$ 의 효과를 주장하였는데 비용이 
더 저렴하였고 시술 후 증상의 호전 정도도 차이가 없었다고 보고하였다. ${ }^{34}$ 그 외 내시경적 시술로는 SO에 대한 botulinum toxin (Botox) 주사, 플라스틱 스텐트 삽입 등이 있는데 이는 추후 EST 전에 치료 반응 유무를 알 수 있는 근거가 될 수 있다고 하였다. ${ }^{32} \mathrm{SOD}$ 에 대한 외과적 치료(surgical sphincterotomy)는 EST가 개발된 후로는 보편적으로 사용되지 않으며 EST가 기술적으로 불가능한 경우에 한하여 시행한다.

담낭 운동장애에 대한 치료로 내과적인 약물 치료 또는 외과적 수술 치료를 시행할 수 있는데, 내과적 약물 치료로는 UDCA와 담낭수축을 증가시키는 약물(예, cholecystokinin, motilin, bethanechol, prostigmine 그리고 erythromycin 등)들을 사용할 수 있으나 그 효과의 한계가 있다. 담낭 운동장애의 현재 표준 치료는 복강경하 담낭절제술이다. 전형적인 통증과 비정상적인 담낭 배출을 보이는 경우 추후 수술을 받을 확률이 $59-100 \%$ 정도이며, 수술 후 91\%에서 증상 호전을 볼 수 있다. 전형적인 통증이 있으나 $\mathrm{GBEF}$ 가 정상인 경우는 자연적 증상 소실이 될 확률이 $80-92 \%$ 정도로 경과 관찰이 원칙이나 일부 지속적인 증상을 계속 보이는 경우 수술시 $57 \%$ 에서 임상적 호전을 보고하였다. ${ }^{35}$ 한편 $\mathrm{GBEF}$ 저하와 $\mathrm{SOD}$ 가 같이 존재하는 경우가 있으며 이런 경우 담낭절제술은 수술 후 통증 악화를 유발시키는 원인이 된다(담낭절제술 후 증후군). 한 연구에서 EST가 담낭 담석의 유무와 관계없이 담낭의 운동기능을
호전시키는 보고도 있어 이에 대한 추가 연구가 필요하다. ${ }^{36}$

\section{6. 담즙성 소화불량에 대한 접근}

만성적인 소화불량 또는 식후 명치 통증을 호소하는 환자에서 상기 기술된 담도 증상을 잘 인지하는 것이 중요한데, 특히 위산역류질환에 사용되는 PPI 제제 등의 약물 치료에도 반응이 없고 과민성 장증후군의 특징인 배변으로의 증상 호전과도 관계가 없으며 췌장염 등에서 볼 수 있는 체위변화에 따른 증상 변화가 없을 때 그리고 특징적인 우상복부 타진성 압통이 있는 경우에 한 번쯤 의심을 해야한다. 검사는 기질적인 질환을 배제하기 위하여 일반적인 내과적 검사와 복부 초음파 검사 그리고 상부소화관 내시경 등을 시행해야 하며, 때에 따라 초음파의 한계를 극복하기 위하여 복부 CT 등을 촬영해 볼 수 있다. 이러한 검사상 전부 정상 소견이 관찰되더라도 일부에서는 초음파 또는 $\mathrm{CT}$ 상 관찰하기 어려운 방사선 투과성 담관 담석, 일부 미세담석, 슬러지 또는 기생충 질환을 감별하기 위하여 내시경초음파 검사가 도움이 되며, 만약 여기에도 정상인 경우 기능성 담관계 질환에 대한 접근을 시도해야 한다(Fig. 1). ${ }^{37}$

기능성 담관계 질환에 대해서 가장 기초적인 검사는 정량적 간담관 신티그라피 검사이며 담낭 운동이상, SOD 또는 복합형을 감별할 수 있다. 충분한 식이 조절과 필요시 약물 치료를 먼저

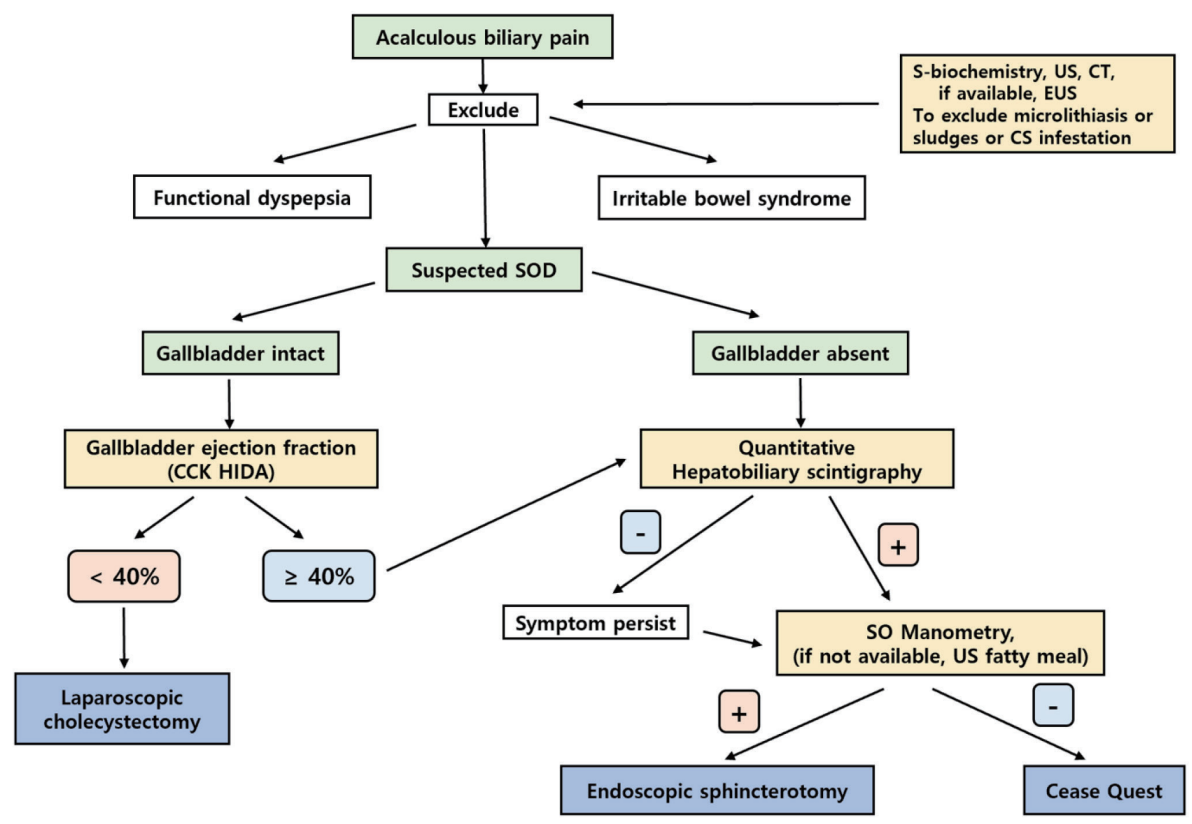

Fig. 1. Algorithms to approach the acalculous biliary pain (ABP) (modified from Catalano et al. ${ }^{37}$ ). US, ultrasound; $C T$, computed tomogram; EUS, endoscopic ultrasound; CS, Clonorchis Sinensis; SOD, sphincter of Odd dysfunction; CCK HIDA, cholecystokinin hepatobiliary; SO, sphincter of Oddi. 
시행하되 증상이 악화되거나 자주 재발을 하는 경우는 다음 치료 단계로 넘어간다. 담낭 운동이상(GBEF가 $40 \%$ 미만)만 있으면 복강경하 담낭절제술을 시행하고, 만약 SOD가 의심 되거나 합당한 소견이 관찰되는 경우는 $\mathrm{SOM}$ 후 결과에 따라 $\mathrm{EST}$ 를 고려해야 한다. SOM이 가용하지 않은 경우에는 자극 초음파 검사를 추가하여 판단을 해야 하며 SOD 2형은 EST를 시행할 수 있으며 SOD 제3형은 EST 시행에 신중을 기해야 한다. EST 전 치료 반응을 평가하기 위하여 스텐트 삽입이나 Botox 주입은 하나의 선택 옵션이 될 수 있다.

\section{결 론}

소화불량증은 외래에서 흔히 접할 수 있는 질환이나 실제적 으로 담즙성 소화불량증에 대한 이해가 부족한 실정이다. 담관계 증상에 대한 폭 넓은 이해와 인지가 필요하며 소화불량증 환자에서 병력 청취 및 이학적 소견이 질환의 감별에 중요하다.

기능성 담관계 질환을 진단하기 위해서는 특징적인 담관계 증상에 대한 이해가 필요하고 적절한 이학적 검사를 시행해야 하며 여러가지 영상의학적인 검사를 감별을 위해서 시행해야 한다. 기능 진단을 위해서는 침습적인 SOM 검사가 있으나 검사의 현실적 실용성 및 검사 자체의 한계가 있으며 이에 대하여 최근 비침습적인 여러 가지 검사에 대한 연구가 활발 하다. 비침습적인 검사에는 약물 유발 검사, 다양한 자극 검사 그리고 정량적 간담도 신티그라피가 있다.

$\mathrm{SOD}$ 의 치료는 내과적 치료, 내시경적 치료 및 수술적 치료가 있으며 현재의 표준 치료는 EST이다. SOD 제 1 형 및 SOM 상 양성 소견을 나타내는 제2형은 비교적 EST에 반응이 좋으며, 제3형은 검사 결과 및 치료에 대한 반응이 다양하여 치료의 선택에 신중을 기해야 할 것이다.

담낭 운동장애 대한 치료로는 내과적 치료, 그리고 표준 치료로 복강경하 담낭절제술을 시행할 수 있다. 하지만 SOD가 동반된 경우에는 일부 EST로 호전되는 경우도 있다.

\section{요 약}

소화불량증은 매우 흔한 질환으로 기존의 위장관계에 발생되는 기능성 소화불량증과 이에 대비되는 췌담관성 소화불량증이 있다. 그 중 담관계 소화불량증을 담즙성 소화 불량증이라 하며 심해지면 담관통도 유발할 수 있다.

비결석성 담관통은 기존 담도계 증상의 원인으로 잘 알려진
담석증, 담도 종양, 협착 등이 없이 발생되는 증상으로 복부 초음파나 CT로 진단되지 않은 미세담석증, 슬러지, 간디스토마 등의 기생충 질환, 그리고 기능성 담관계 질환 등이 있으며 감별을 위하여 내시경초음파 검사가 도움이 된다. 기능성 담관계 질환의 확진을 위하여 SOM 검사를 시행하고 있으나 현실적 실용성 및 검사 자체의 침습성 및 판독의 한계가 있으며 이에 대하여 최근 비침습적인 여러가지 검사에 대한 연구가 활발하다.

실제적으로 기능성 담관계 질환을 진단하기 위해서는 가장 임상적으로 쉽게 해 볼 수 있는 검사는 정량적 간담관 신티그라피 검사이며 담낭 운동이상, SOD 또는 복합형을 감별할 수 있다. 치료는 충분한 식이 조절과 약물 치료를 먼저 시행하되 증상이 악화되거나 자주 재발을 하는 경우는 담낭 운동이상만 있으면 복강경하 담낭절제술을 시행하고, 만약 SOD가 의심되거나 이에 합당한 소견이 관찰되는 경우는 추가적으로 $\mathrm{SOM}$ 을 시행한 후 결과에 따라 $\mathrm{EST}$ 를 고려해야 한다. SOM이 가용하지 않은 경우에는 자극 초음파 검사를 추가로 시행하여 판단을 해야 하며 SOD 2형은 EST를 시행할 수 있으며 SOD 제3형은 환자 선택에 신중을 기해야 할 것이다.

국문 색인: 담즙성 소화불량증, 담낭 운동장애, 오디괄약근 기능이상증, 간담도 신티그라피

\section{Conflicts of Interest}

The author has no conflicts to disclose.

\section{REFERENCES}

1. Barbara L, Camilleri $M$, Corinaldesi $R$, et al. Definition and investigation of dyspepsia. Consensus of an international ad hoc working party. Dig Dis Sci 1989:34:1272-1276.

2. Drossman DA, Hasler WL. Rome IV-functional GI disorders: disorders of gut-brain interaction. Gastroenterology 2016;150:1257-1261.

3. Oustamanolakis P, Tack J. Dyspepsia: organic versus functional. J Clin Gastroenterol 2012;46:175-190.

4. Koch M, Capurso G. Functional dyspepsia: how could a biliary dyspepsia sub-group be recognized? A methodological approach. Ital J Gastroenterol 1996;28:261-268.

5. The epidemiology of gallstone disease in Rome, Italy. Part I. Prevalence data in men. The Rome Group for Epidemiology and Prevention of Cholelithiasis (GREPCO). Hepatology 1988;8:904-906.

6. Prevalence of gallstone disease in an Italian adult female population. Rome Group for the Epidemiology and Prevention of Cholelithiasis (GREPCO). Am J Epidemiol 1984;119:796-805.

7. Bielefeldt K. The rising tide of cholecystectomy for biliary dyskinesia. 
Aliment Pharmacol Ther 2013:37:98-106.

8. Drossman DA, Li Z, Andruzzi E, et al. U.S. householder survey of functional gastrointestinal disorders. Prevalence, sociodemography, and health impact. Dig Dis Sci 1993;38:1569-1580.

9. Lee H, Jung HK, Huh KC; Functional Dyspepsia Study Group in the Korean Society of Neurogastroenterology and Motility. Current status of functional dyspepsia in Korea. Korean J Intern Med 2014;29:156-165.

10. Yap L, Wycherley AG, Morphett AD, Toouli J. Acalculous biliary pain: cholecystectomy alleviates symptoms in patients with abnormal cholescintigraphy. Gastroenterology 1991;101:786-793.

11. Cotton PB, Elta GH, Carter CR, Pasricha PJ, Corazziari ES. Rome IV. Gallbladder and sphincter of Oddi disorders. Gastroenterology 2016;150:1420-1429.e2.

12. Dibaise JK. Evaluation and management of functional biliary pain in patients with an intact gallbladder. Expert Rev Gastroenterol Hepatol 2009;3:305-313.

13. Mayer EA, Gebhart GF. Basic and clinical aspects of visceral hyperalgesia. Gastroenterology 1994;107:271-293.

14. Kalloo AN. Overview of differential diagnoses of abdominal pain. Gastrointest Endosc 2002;56(6 Suppl):S255-S257.

15. Sherman $S$, Lehman GA. Sphincter of Oddi dysfunction: diagnosis and treatment. JOP 2001;2:382-400.

16. Behar J, Corazziari E, Guelrud M, Hogan W, Sherman S, Toouli J. Functional gallbladder and sphincter of Oddi disorders. Gastroenterology 2006;130:1498-1509.

17. Ruffolo TA, Sherman S, Lehman GA, Hawes RH. Gallbladder ejection fraction and its relationship to sphincter of Oddi dysfunction. Dig Dis Sci 1994;39:289-292.

18. Sherman S, Troiano FP, Hawes RH, O'Connor KW, Lehman GA. Frequency of abnormal sphincter of Oddi manometry compared with the clinical suspicion of sphincter of Oddi dysfunction. Am J Gastroenterol 1991;86:586-590.

19. Eversman D, Fogel EL, Rusche M, Sherman S, Lehman GA. Frequency of abnormal pancreatic and biliary sphincter manometry compared with clinical suspicion of sphincter of Oddi dysfunction. Gastrointest Endosc 1999;50:637-641.

20. Luman W, Williams AJ, Pryde A, et al. Influence of cholecystectomy on sphincter of Oddi motility. Gut 1997;41:371-374.

21. Kim JH. Motility disorder of biliary tract. The 7th PG Course of Korean Society of Gastroenterology 1998:45-49.

22. Lee JK. Review : Functional disorders of the biliary tract. Kor J Neurogastroenterol Motil 2002;8:131-138.

23. Sgouros SN, Pereira SP. Systematic review: sphincter of Oddi dysfunction-non-invasive diagnostic methods and long-term outcome after endoscopic sphincterotomy. Aliment Pharmacol Ther 2006;24:237-246.

24. Steinberg WM, Salvato RF, Toskes PP. The morphine-prostigmin provocative test--is it useful for making clinical decisions? Gastroenterology 1980;78:728-731.

25. Mariani A, Curioni S, Zanello A, et al. Secretin MRCP and endoscopic pancreatic manometry in the evaluation of sphincter of Oddi function: a comparative pilot study in patients with idiopathic recurrent pancreatitis. Gastrointest Endosc 2003;58:847-852.

26. Sostre S, Kalloo AN, Spiegler EJ, Camargo EE, Wagner HN Jr. A noninvasive test of sphincter of Oddi dysfunction in postcholecystectomy patients: the scintigraphic score. J Nucl Med 1992;33:1216-1222.

27. Corazziari E, Cicala M, Habib Fl, et al. Hepatoduodenal bile transit in cholecystectomized subjects. Relationship with sphincter of Oddi function and diagnostic value. Dig Dis Sci 1994;39:1985-1993.

28. Cicala M, Habib Fl, Vavassori P, et al. Outcome of endoscopic sphincterotomy in post cholecystectomy patients with sphincter of Oddi dysfunction as predicted by manometry and quantitative choledochoscintigraphy. Gut 2002;50:665-668.

29. Thomas PD, Turner JG, Dobbs BR, Burt MJ, Chapman BA. Use of (99m) TC-DISIDA biliary scanning with morphine provocation for the detection of elevated sphincter of Oddi basal pressure. Gut 2000;46:838-841.

30. Rosenblatt ML, Catalano MF, Alcocer E, Geenen JE. Comparison of sphincter of Oddi manometry, fatty meal sonography, and hepatobiliary scintigraphy in the diagnosis of sphincter of Oddi dysfunction. Gastrointest Endosc 2001;54:697-704.

31. Williams W, Krishnamurthy GT, Brar HS, Bobba VR. Scintigraphic variations of normal biliary physiology. J Nucl Med 1984;25:160-165.

32. Behar J, Corazziari E, Guelrud M, Hogan W, Sherman S, Toouli J. Functional gallbladder and sphincter of Oddi disorders. Gastroenterology 2006;130:1498-1509.

33. Lee SK, Kim MH, Kim HJ, et al. Electroacupuncture may relax the sphincter of Oddi in humans. Gastrointest Endosc 2001;53:211-216.

34. Arguedas MR, Linder JD, Wilcox CM. Suspected sphincter of Oddi dysfunction type II: empirical biliary sphincterotomy or manometryguided therapy? Endoscopy 2004;36:174-178.

35. Shaffer EA. Cholescintigraphy in acalculous biliary pain: if abnormal, should cholecystectomy follow? Hepatology 1992;15:737-739.

36. Agarwal DK, Sharma BC, Dhiman RK, Baijal SS, Choudhuri G, Saraswat VA. Effect of endoscopic sphincterotomy on gallbladder motility. Dig Dis Sci 1997;42:1495-1500.

37. Catalano MF, Thosani NC, Howell DA, Grover S. Clinical manifestations and diagnosis of sphincter of Oddi dysfunction [Internet]. UpToDate; 2018 [updated 2018 July 2]. Available from: https://www.uptodate. com/contents/clinical-manifestations-and-diagnosis-of-sphincterof-oddi-dysfunction? search=Clinical $\% 20$ manifestations $\% 20$ and $\% 20$ diagnosis $\% 20$ of $\% 20$ sphincter $\% 20$ of $\% 200$ dd $\% 20$ dysfunction.\&source=search_result\&selectedTitle $=1 \sim 150 \&$ usage_ type $=$ default $\&$ display_rank $=1$. 